\title{
Trade Service Practices in Bangladesh - An Analysis
}

\author{
S. M. A. Habib and P. Shah
}

\begin{abstract}
The availability of finance and other relevant services is crucial for a healthy trading system, and to be effective, adequate financing and other support services backed by mature financial industries are essential. In Bangladesh, trade is the key component of international business activities, and trade facilitation is directly connected with the country's global integration. As part of trade facilitation, banks facilitate payment, finance and risk management services to the traders and thus contribute to growing global trade integration of Bangladesh and other economies of the world. The paper is about reviewing and analyzing the trade services activities of Bangladesh. Based mainly on the secondary information, the study found that documentary credit has been the key trade facilitation instrument of the country and thus other financing tools are mainly associated with that of LC. Of the challenges compliance and trade based money laundering are identified as the key concerns in the area of trade services.
\end{abstract}

Index Terms-Trade finance, documentary credit, open account, transport document.

\section{INTRODUCTION}

Trade services practice or the availability of finance and other relevant services or trade facilitation is crucial for a healthy trading system. These services by banks and financial institutions become particularly essential since in many instances importers and exporters are unwilling to bear trade related commercial risks. Today, it is well recognized that expansion of trade service activities by banks and financial institutions are connected with the expansion of cross-border trade flows and both developed and developing countries have been playing increasingly prominent role [1].

Today, up to 80 percent of global trade is supported by some sort of financing however, there are significant gaps in provision and therefore many companies cannot access the financial tools that they need [2]. Without adequate trade finance, businesses are affected, and opportunities for growth and development are not attained. The most recent ICC survey provided us encouraging data in which it has been reported that the availability of trade finance activities and banks are now have greater capacity to satisfy their customers demand for trade finance [3]. However, trade finance gap

Manuscript received January 5, 2017; revised April 3, 2017.

S. M. A. Habib is with Bangladesh Institute of Bank Management [BIBM], Bangladesh (e-mail: ahsan@ bibm.org.bd).

P. Shah is with the Faculty of Business, University of Liberal Arts Bangladesh (ULAB), Bangladesh (e-mail: pinki11march@gmail.com). remained a critical challenge. Available data indicate that gaps are increasingly pronounced in emerging economies [4]. Global trade finance markets and participants are also facing some newer challenges with the growing business complexities, changing global political scenario and decelerating confidence amongst parties and market players.

In the context of Bangladesh, trade is the key component of international business activities, and trade facilitation is directly connected with the country's global integration. As part of trade facilitation, banks facilitate payment, finance and risk management services to the traders and thus contribute in growing global trade integration of Bangladesh and other economies of the world. The paper is about reviewing and analyzing trade services i.e. trade payment and financing practices of Bangladesh. The specific objectives of the paper are: to discuss trade services operation and regulatory aspects in global context; to discuss regulatory and operational aspects of trade services of banks in Bangladesh; and to examine the trends and challenges of trade services operations of banks in the context of Bangladesh.

The paper is mainly based on secondary information. Alongside several review studies and surveys' on trade services in global and Bangladesh context, senior bank executives of a number of banks were consulted to perform the study.

\section{Regulatory SET UP AND TRENDS IN TRADE SERVICES PRODUCTS IN GLOBAL MARKET}

\section{A. Regulatory Set up in Global Trade Service Market}

'Purchase/sale agreement' is the contract between exporter and importer, the starting of a trade transaction. Though some common contents are expected in a purchase/sale agreement, there is no doubt that terms and conditions of purchase/sale contract would vary for different products, modes of payment or even sources of imports. In case of three methods of payments (cash in advance, open account and documentary collection), sales/purchase contract is the guiding document. The United Nations Convention on Contracts for the International Sale of Goods (CISG), which is popularly known as Vienna Convention provides a uniform framework for contracts of sale of goods. As of end December 2015, UNCITRAL reported that 84 States have adopted the CISG, which account for a significant proportion of world trade. Under the treaty, the parties, which come from all legal traditions, having different economies together account for over two thirds of global commercial exchanges ${ }^{1}$. Though as trade payment techniques, cash in advance and open account are guided by the purchase/sale agreement, documentary

\footnotetext{
${ }^{1}$ https://www.uncitral.org
} 
collection is collectively guided by the purchase/sale contract and Uniform Rules for Collections (URC 522), an ICC publication. Uniform Rules for Collection of ICC contains the set of rules to guide collection process through banks, which is known as 'Documentary Collection'. The ICC Uniform Rules for Collections are a practical set of rules to aid bankers, buyers, and sellers in the collections process.

Documentary credit or LC is guided by a classic set of rules called as Uniform Customs and Practice for Documentary Credit (UCPDC). The current version of UCPDC, is the collection of rules governing the issuance and execution of letters of credit in the cross border exportation and importation in the global economy. UCP, the popular title of UCPDC, compiles the best documentary credit practices that came into effect from July 1, 2007 and is the seventh revision of the rules since they were first promulgated in 1933. The 39 articles of UCP 600 mainly cover the liabilities and responsibilities of different parties engaged in the process of LC which is meant for traders and bankers. The universal acceptance of the UCP by practitioners in countries with widely divergent economic and judicial systems is a testament to the rules' success. The eUCP is a supplement to the UCP that, when used in conjunction with the UCP, provides the necessary rules for the presentation of the electronic equivalents of paper documents under letters of credit. This electronic supplement came into force on April 1, 2002. To ensure complying presentation, bankers are required to follow another document published by ICC called International Standard Banking Practice (ISBP 745) which provides important guidance to documentary credit examiners and practitioners relating to the examination of documents presented against which is a valuable supplementary guide to UCP. In most cases under LC, reimbursement by the issuing bank is made using the service of a third bank and the process is known as Bank-to-Bank Reimbursement Arrangement. It has been referred to in article 13 of UCP 600; however, the process is guided by a separate ICC set of rules titled, Uniform Rules for Bank-to-Bank Reimbursements under Documentary Credits (URR 725) which came into effect from October, 2008.

Of the other major rules/guidelines, International Standby Practices (ISP98) is designed to become the industry standard for the use of standbys in international transactions. Uniform Rules for Demand Guarantees (URDG 758) is the guiding framework applicable to the demand guarantee and counter guarantee practices that came into force in July 2010. In the area of guiding trade services, Uniform Rules for Bank Payment Obligation (URBPO) and Uniform Rules for Forfaiting (URF 800) are relatively recent developments. URBPO has been launched as the standard for supply chain finance that is expected to facilitate international trade. International commercial terms or incoterms are relevant for all types of cross border trade transactions and facilitations. The current version, Incoterms 2010 came into effect from the 1st January 2011.

\section{B. Product Trends in Global Trade Service Market}

Some commonly used trade services techniques in international trade are cash in advance, open account, documentary collection, documentary credit (LC), standby
LC or other bank guarantees, bank payment obligation, supply chain financing, factoring, forfeiting etc. In some of these trade facilitation or trader service techniques, involvements of banks are insignificant like cash in advance and open account. In cash in advance, the buyer places the funds at the disposal of seller (exporter) prior to shipment of goods in accordance with the sales/purchase contract. Though generally, banks are engaged only in transferring payment from one country to another in cash in advance, sometimes banks offer advance payment guarantees to the importer on behalf of exporter. Globally, use of cash in advance is relatively less. Open account is the reverse of cash in advance. This is an arrangement between the buyer and seller whereby the goods are manufactured and delivered before payment is required. Again generally, banks involvement is insignificant in case of open account payment technique. However, in some cases, the lag between shipment and payment may require the extension of credit during the period involved. Such credit may be through a banker's acceptance under which the bank accepting a draft assumes the obligation of making the payment at maturity on behalf of the buyer.

Involvements of banks are significantly higher in the trade services techniques like LC, bank guarantee, standby LC and documentary collection. Especially, through LC banks offer payment, financing and risk management services to its clients. Documentary Credit or LC is a classic form of international trade payment method that substantially reduces risks for both exporter and importer. It is an undertaking or commitment issued generally by a bank to pay the exporter a certain amount provided that the terms and conditions of the documentary credit are complied with. The conditions are about submission of certain documents in certain form. Documents must be in order to receive payment. A standby LC is functionally equivalent to demand guarantee or international bank guarantee, but differs in terms of structure. International guarantees are availed for commercial and non-commercial purposes. The demand guarantees may serve several purposes from indefinite range of payment, performance or non-performance obligation. Documentary collection is basically a payment technique that includes 'documents against payment' and 'documents against acceptance' techniques that provides a means of payment whereby the exporter can ensure that the buyer should not be able to take possession of the goods until it has paid or given a payment undertaking. Documentary collection is appropriate to cases in which the seller is unwilling to provide the merchandise on open account terms but does not need a bank undertaking such as a documentary credit.

Some of the trade services/finance products are relatively recent development like Bank Payment Obligation (BPO), Supply Chain Finance (SCF, factoring. BPO is a payment tool offering a level of security similar to that of a letter of credit. The BPO is an irrevocable undertaking on the part of an obligor bank (typically that of a buyer) to recipient bank (typically that of a seller) to pay a specified amount on agreed date on condition of a successful matching of electronic data according to rules adopted by the ICC. Using SCF banks provide technology and other services to facilitate payments and financing within supply chain of enterprises. The services within a SCF platform include typical elements of financing 
for international trade (like pre-shipment and post-shipment financing, purchases and discounting of receivables, etc.) but not LCs. The objective of such a platform is to bring within a single unit of bank financial services related to supply, storage, cross-border relations between sellers and buyers, distribution, and final sales to customers. International factoring is the sale of assignments of short-term accounts receivable arising from an international sale of goods or services. The technique is associated with handling risk in open account trade. The international factoring business involves networks similar to the use of correspondents in the banking industry. Forfaiting is used to denote the purchase of obligations falling due at some future date, arising from deliveries of goods and services. Factoring is suitable for financing smaller claims for consumer goods, whereas forfaiting is used to finance capital goods exports.

In connection with the product mix of trade service products, on the import side, as a whole the use of documentary credit increased (ICC Survey). Commercial letters of credit on the import side comprised around 43 percent of the import finance product mix, up from 36 percent from the previous year [5]. Standby LCs remained constant with slightly higher than 9.31 percent, just a shade above the figure of the previous year. An interesting observation from the reported figures is that bank guarantees, as part of the import trade finance product mix fell quite sharply. The key proposition to this reported decline in demand for guarantees as part of the overall product mix is that due to the economic slowdown in some major emerging markets there is related decline in infrastructure and construction and shipbuilding contracts, all sectors which have major impact on the use of bank guarantees and bonds. Though there are arguments/opinions that given the progress being made in electronic trade payment platforms, the expansion of factoring, short term export credit insurance and other supply chain products, the popularity of LC may go down sharply. However, as has been proven countless times, the demise of the commercial letter of credit is not imminent by any means, as has been proven repeatedly over a period of several decades [5].

Not very different from importation, in export trade commercial letters of credit as a proportion of overall trade finance products registered a slow but steady growth phase as part of the product mix. Commercial letters of credit made up 44.36 percent in the 2015 survey increasing from 41 percent in the 2014 survey [5]. According to the observation of ICC, recent instability in some the top global trade markets combined with the current perception of increased risk of default for goods and services exported is shaping this development. The ICC survey also reported that for export transactions Standby Letters of Credit make up 7.7 percent of the mix, which is an increase from 5 percent in the 2014 survey. The figure for guarantees came in at 12.71 percent of the overall export trade finance product mix.

The figures of 15.03 percent open account for import product mix and 14.77 percent for open account in export mix transactions in ICC survey need to be considered within the particular context: respondents to this survey generally originate from traditional trade finance departments and often open account transactions are handled in different departments of their banks. It is recognized globally that open account is the most popular trade facilitation technique [6].

\section{REGULATORY SETUP AND DOCUMENTS IN TRADE SERVICES IN BANGLADESH}

In Bangladesh, trade services products are those services that are commonly offered from the 'Trade Services Department' of a bank. Broadly, trade services products of the country includes products or services related to trade payment and trade finance.

Payment mode is agreed upon in the purchase/sale agreement. At the operational level, two types of payment processing mechanisms are followed: Branch Based and Centralized. Under branch-based arrangement, AD branches of a particular bank conduct their trade service operation not only for their own customers but also for the customer of Non-AD branches. Under centralized arrangement, trade services are offered through a centrally managed department or unit. Sometimes a hybrid arrangement is followed under which customers of non-AD branches are served from a centralized unit and AD branches serve their own customers.

Bangladesh Bank, the central bank of the country, is the regulatory authority for regulating and supervising all trade services activities. Practically, ADs offer services as the agents or dealers of the central bank. BB has also been playing role in ensuring coordination among stakeholders for greater efficiency. Banks are required to follow both a set of domestic regulations and international rules/guidelines while offering trade services. In this connection, our exchange control regulation i.e., Foreign Exchange Regulations Act 1947 (FERA 1947) is the key domestic regulation in regulating cross-border banking transactions. FERA, 1947 has empowered Bangladesh Bank to regulate all kinds of foreign exchange dealings in Bangladesh. Bangladesh Bank issues licenses to the selected bank branches for conducting trade payments, financing and other international banking operations empowered by the Act. As per the Act, Bangladesh Bank issues circulars/guidelines from time to time to regulate trade payment, financing, remittance services etc. activities to be followed by the banks. Banks are also required to follow the trade policies issued by the Ministry of Commerce of Bangladesh. Among the international rules and guidelines, International Chamber of Commerce (ICC) publications are the most relevant. Of the ICC regulations, UCPDC, URC, URR, ISBP and Incoterms are particularly relevant for the country.

Commercial invoice, transport documents, insurance documents, bill of exchange etc. are the most commonly used documents in trade transactions. The requirements and nature of documents depends upon purchase/sale agreement. In case of LC, these documentary requirements are noted in the LC itself. For selecting right documents, the trading parties should consider both domestic and international regulations carefully. In practice sometimes commercial invoice may not be signed. UCP 600 does not require a commercial invoice to be signed. But as per the domestic requirement of Bangladesh, commercial invoice has to be signed. Bill of lading is the most commonly used transport document or in case of multimodal 
transport document ocean mode is the base. As per domestic rules of Bangladesh, importable is to be released to the order of a bank. Blank-back or short form transport documents are not accepted in the country. As per the domestic requirement of Bangladesh, insurance coverage is to be given by domestic insurance companies for imports. Traders are very familiar with the bill of exchange and its format. In Bangladesh, traditionally customs authority asks for bill of exchange at the time of releasing of goods. Under the Stamp Act the amount accepted in the bill of exchange for usance payment is dutiable. Considering the practice of Bangladesh, other documents may include certificate of origin, PSI certificate, weight list, phyto-sanitary certificate, health certificate, fumigation certificate, radiation certificate, quarantine certificate etc. In case of import to Bangladesh, barring a few exceptions obtaining certificate of origin is a regulatory requirement. The mandatory PSI requirement for importation has been withdrawn since mid-2013. Phyto-sanitary or health certificates are commonly required in connection with importation of foods.

\section{TRends And Challenges In TRADE SERVICE PRACTICES IN BANGLADESH}

Banks facilitate trade payments i.e. export proceeds and import payments flow in and flow out respectively through banking channels. Though there were variations in growth, both the volumes of export proceeds and import payments increased over the years. In regard to the facilitation of the trade process, contributions of the Private Commercial Banks (PCBs) were the most during CY2011-2014 [6].

The BIBM Survey data clearly indicate the extensive use of documentary credit in import transactions in Bangladesh, not different from the previous year [6]. In 2014, 84 percent (in terms of number of cases) and 88 percent [in terms of volume of imports] import payments from the country were made through LC. In terms of percentages, the figures are even higher than that of 2013, and LC remains the single most common method in use. There are differences in regard to the use of LC by different categories of banks. Collection is mainly facilitated by the Foreign Commercial Banks (FCBs) of the country that generally have better international linkages and client base.

As in the case of import payment, LC was the most widely used method to receive payment by the exporters of Bangladesh during CY 2014. The survey data indicate, in 56 percent (in terms of number of cases) cases of exports, LC payment methods were used that amounted to 57 percent of the total export receipts [6]. Like the case of import, use of LC decreased a bit as compared to that of the CY 2011. However, as compared to the methods of import payments, uses of documentary collection are much higher in case of export receipts.

In Bangladesh, all LCs opened are irrevocable in nature as required by the import policy order of the country. Under UCP 600 also LC means irrevocable LC. Of the special type of LC, a significant number is back-to-back. This is because of the garments sector that imports raw materials from abroad for meeting their export orders. Practically, the demand for confirmed credit increased following the global crisis of
2008-09. The number and volume of the increased confirmed letter of credit since CY 2012 can be explained by the increasing use of UPAS in Bangladesh that requires confirmation on the part of the financing bank. The decrease in the confirmed credit in CY 2014 may indicate an indication of getting back of the global economy to the normalization.

As the survey result of BIBM shows, in case of all the documentary credit opened from the country in CY 2014, issuing banks asked for transport documents (bill of lading, airway bill, truck receipt etc.), commercial invoice and certificate of origin. No change is observed in regard to the use of documents in between CY2011 and CY2014. In Bangladesh, insurance documents are rarely asked as according to the country's import policy, insurance is to be covered by domestic importers (as a measure to restrict foreign currency outflow and promoting domestic insurance companies). In case of export LC, the documentary requirements are almost same. It can be observed from the survey data that insurance documents are less frequently asked in the LCs sent to Bangladesh exporters (not very different from the LC opened by banks located in Bangladesh for foreign exporters). Such practice points to the similar regulatory requirement in the trade partner countries under which insurance formalities are to be covered by their domestic insurance companies.

Banks generally ask for some margin that varies from 0 to 100 percent and from client to client. The margin is determined by the head offices or in some cases branch heads based on banks' relationship with the clients. The survey data reveal that the extreme cases of 0 percent or 100 percent are insignificant in number and in most cases the margins fall around 10-20 percent.

According to the opinions of survey respondent banks prefer to select those banks as advising banks with which they have correspondent relationships. Some banks also try to accommodate exporters' choice. It has been observed that a few banks are a bit rigid in selecting advising banks because of maintaining their business relationship or commission sharing with the counter parties. To accommodate exporters choice banks sometimes avail the services of second advising banks (very less instances). Almost in all cases, confirming banks are selected by issuing bank, however, sometimes banks try to accommodate exporters' choice if they have arrangement with the banks. In recent time there were increases in the exporters' preferences in choosing confirming banks.

For amendment of letters of credit, generally importers approach to the issuing bank on behalf of exporters. Though, some issuing banks ask for letter, mail etc. to ensure exporters consent in this connection, still they hardly find amendment risky for themselves. According to the observation of survey respondents, most of these amendments go in favour of exporters and so risks of accepting or rejecting is minimum. The most common amendments from Bangladesh are extension of expiry date and last date of shipment. In case of amendment from abroad, the requirement of 'to order of bank' of Bangladesh or statement of 'transferability' are ensured through amendment [7].

In regard to the availability of the credit, in most cases banks offer scope for negotiation in Bangladesh. In most 
cases (as the BIBM survey data indicate), the LC issued from the country are freely available which means any bank is nominated bank at the counter of which documents are submitted by the foreign exporter/beneficiary. In such a case, exporter can submit documents at the counter of its own bank in the country of his/her domicile. Some banks (mainly FCBs and a few PCBs) however prefer to restrict negotiation at the counter of certain banks having correspondence relationship.

Volume of trade finance i.e. export and import financing of the banking sector increased over the years and major portion of trade finance facilities of the country were offered by the PCBs. State controlled banks (SCBs) are the major contributors in export finance market in Bangladesh with over half of the total. Of the pre-shipment finance, packing credit is the main component and of the post shipment credit it is the purchasing or discounting of foreign bills or negotiation is the most common products.

Import financing mainly include payment against documents (PAD), loan against imported merchandize (LIM) and loan against trust receipt (LTR). This segment is clearly dominated by the PCBs of Bangladesh.

As the survey data reveal, most international bank guarantees received in Bangladesh are indirect or counter guarantees. Government sector is the main recipients of international bank guarantees in Bangladesh mainly in the area of infrastructure and public procurement. Of the other areas, RMG receives bank guarantee as securities against export under documentary collection.

About international bank guarantees, most of the bank guarantees issued from Bangladesh is direct guarantees and these are performance guarantees. Other major type of bank guarantee is advance payment guarantees for trade purposes. Indirect guarantees are issued mainly to support government sectors. Bank guarantees issued to obtain foreign loans is a relatively recent development in the country.

Trade services by banks of the country are facing several challenges. Identification of factitious discrepancy in documents of submitted under LC has been a common problem. In several instances the banks of the country faced the fraudulent activities in recent time. As in other global economies, challenges of correspondent banking relationship and compliance are amongst the growing concerns. In Bangladesh, money laundering activities are mainly trade based. Among the four basic techniques of trade based money laundering (TBML) i.e. over and under invoicing of goods and services, over and under shipment of goods and services, multiple invoicing and falsely described goods and services, first and fourth techniques are common in use for money laundering in Bangladesh. Though the main motive behind the TBML is to hide the proceeds of crime but in some cases government subsidies and tax/duty evasion instigate perpetrator to engage in money laundering. To hide or profitable use of the proceeds of crime through illicit outflows of funds from Bangladesh the criminals use over pricing in import, generally low duty item like capital machineries, raw materials and spare parts and underpricing of export. For gaining government benefit like cash incentives, subsidies there are tendencies of over pricing of exported items. Apparently, these are frequently used trade based money laundering tools as observed by BB. Consultations with the senior bank officials indicate that compliance and reporting are key challenges.

\section{SUMMARY OBSERVATION AND CONCLUSION}

Documentary credit remained the most prominent payment technique in import and export transactions in Bangladesh. Though the extensive use of documentary credit started in response mainly to the regulatory compulsion, LC remained the most dominant even after removing restrictions on some areas of transactions. This is sharp contrast to the global practice in general where almost four-fifth payment transactions take place through open account. Documentary collection remained the second most important trade facilitation tool in the country. Of the financing techniques packing credit, negotiation of export bills, PAD, LIM, LTR are commonly used products. Of the challenges, there are also apparent incidences of trade based money-laundering. Thus as in global trade service market compliance and reporting are key concerns for banks.

Though the available sets of AML rules are in line with globally accepted standards, still there is lot of scopes to improve their enforcements. ADs need to be more serious regarding legal compliance and identifying right prices for the exportable and importable products, as observed from the discussion with Bangladesh Bank. Compliance of AML rules should be a collective concern. Integration and seamless flow of information exchange on export and import items among $\mathrm{BB}$, Customs and all commercial banks could be very effective. Since the obligation of ensuring the prices of importable items are 'competitive' and the price of exportable item are 'fair' lays with banks so, they have to find out an effective mechanism to implement the obligation. This can be materialized by establishing consolidated trade database.

Enforcement of online reporting and monitoring system by the Bangladesh Bank have brought positive changes in terms of decline in irregularities by banks and improvement in data accuracy. However, still there are instances of some common mistakes on the part of the banks. BB is working to improve reporting efficiency by offering training; however, more training is needed to ensure greater efficiency and minimizing information gap. Improvements were observed in regard to the monitoring and coordination among stakeholders. Further improvement in coordination and transparency would help attaining greater efficiency.

\section{REFERENCES}

[1] BIS "Trade finance: Developments and issues," Committee on the Global Financial System, CGFS Papers, BIS, 2014

[2] WTO, "Trade fianance and SMEs," Switzerland, 2016.

[3] ICC, "Rethinking trade and finance- survey of trade finance," Paris, France, 2015.

[4] ADB, "ADB BRIEFS trade finance gap," Growth, and Jobs Survey, no. 25, ADB, 2014.

[5] Bangladesh Bank, "Economic trends," Statistics Department, Dhaka, 2015 .

[6] S. M. A. Habib, S. Alam, Z Antara, and N. Haque, "Review of the trade services operations of Banks 2014," Banking Review Series 2015 Bangladesh Institute of Bank Management, 2015

[7] S. M. A. Habib, Z. Antara, T. Ahmed, N Haque, M. Rahman, and K Hossain, "Review of the trade services operations of Banks 2015," Bangladesh Institute of Bank Management, 2016. 


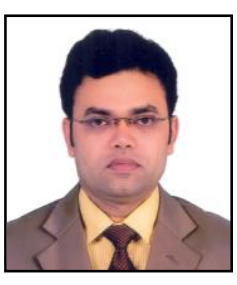

S. M. A Habib was born in January 1, 1972 in Bangaldesh, he is a professor and director [Training] of Bangladesh Institute of Bank Management [BIBM] - the national Training, Research, Education and Consultancy institute on banking and finance in Bangladesh. He obtained his $\mathrm{PhD}$ in international finance from Banaras Hindu University, India under BHU Research Scholarship; and accomplished Post Doctoral Fellowship on Green Banking from Syracuse University, USA under Senior Fulbright Scholarship.

Dr. Habib is a professional trainer in banking and finance mainly in the areas of trade services, green financing, and SME and inclusive financing. His research areas include trade services, foreign exchange, financial inclusion and green banking, SME banking. He has teaching experiences with several universities including Dhaka University, BRAC University, East West University etc. as adjunct faculty. He has over hundred publications and research articles in national and international journals and periodicals; and more than eighty news-paper features in English and Bangla national dailies.

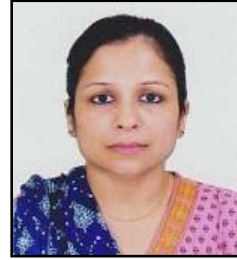

P. Shah was born in August 13, 1972 in India, is an associate professor of the Faculty of Business, University of Liberal Arts Bangladesh (ULAB) - a reputed private university in Bangladesh. She obtained masters in Economics from Bananras Hindu Unievrsity, India in 1995, and awarded PhD in international trade from Purbanchal University, India in 2004.

Dr. Shah has academic and reserch interests in trade services, international busienss, and women studies. She is the founder president of Porfessoional Women's Associtaion (ProWA)- an association of the women university teachers and researchers in the ountry. 